\title{
Wnt signaling in the intestinal epithelium: from endoderm to cancer
}

\begin{abstract}
Alex Gregorieff and Hans Clevers ${ }^{1}$
The Wnt pathway controls cell fate during embryonic development. It also persists as a key regulator of homeostasis in adult self-renewing tissues. In these tissues, mutational deregulation of the Wnt cascade is closely associated with malignant transformation. The intestinal epithelium represents the best-understood example for the closely linked roles of Wnt signaling in homeostatic self-renewal and malignant transformation. In this review, we outline current understanding of the physiological role of Wnt signaling in intestinal biology. From this perspective, we then describe how mutational subversion of the Wnt cascade leads to colorectal cancer.
\end{abstract}

Netherlands Institute for Developmental Biology, Hubrecht Laboratory, 3584 CT Utrecht, The Netherlands

Development and homeostasis in all multicellular organisms depend on a complex interplay between processes involved in cell proliferation, migration, differentiation, adhesion, and death. This diverse array of cellular responses is in large part coordinated by a relatively small number of intercellular signals, examples of which include the BMP, TGF, Notch, Hh, and Wnt pathways. One of the major developments in recent years has been the realization that the signaling pathways triggered by these factors are very often deregulated in pathological conditions (Massague et al. 2000; Polakis 2000; Waite and Eng 2003; Bijlsma et al. 2004; Lefort and Dotto 2004; Moon et al. 2004). This notion is particularly well illustrated by the role of the Wnt pathway in the intestinal epithelium. The relevance of Wnt signaling to intestinal biology was established, unknowingly at the time, more than 10 years ago when the tumor suppressor gene Adenomatous polyposis coli (APC) was found mutated in a large number of hereditary and sporadic cases of CRC (Groden et al. 1991; Kinzler et al. 1991; Nagase and Nakamura 1993). Subsequently, combined work from several laboratories led to the finding that inactivation of APC in CRC cells results in constitutively active Wnt signaling (Rubinfeld et al. 1993; Korinek et al. 1997; Morin et al. 1997). Since these early findings, a much richer picture has emerged. It is now recognized that

[Keywords: WNT; cancer; intestine]

${ }^{1}$ Corresponding author.

E-MAIL clevers@niob.knaw.nl; FAX 31-30-2121-801.

Article and publication are at http://www.genesdev.org/cgi/doi/10.1101/ gad.1295405.
Wnt signaling not only drives tumorigenesis but is also required at different stages of gut development, as well as during adult epithelial homeostasis. Our approach in this review will be to dissect the different functions attributed to Wnt signaling at these various time points. First, we shall begin by introducing some of the components of the pathway most relevant to our discussion.

\section{A short summary of the Wnt pathway}

Wnts and their downstream effectors were originally discovered in Drosophila and subsequently shown to be conserved in all metazoans (Wodarz and Nusse 1998). Genetic and biochemical data taken from these models have, to date, identified $>50$ proteins directly involved in transducing Wnt signals (see The Wnt Homepage, http://www.stanford.edu/ rnusse/wntwindow.html). How these proteins interact with one another to stimulate various biological responses has been an area of intense investigation.

Wnt genes, of which there are 19 in man and mice, encode for cysteine-rich glycoproteins. Production of biologically active Wnts depends on palmitoylation of a conserved cysteine residue (Willert et al. 2003). This process may be mediated by Porcupine/MOM1; however, direct proof for this has not yet been provided /van den Heuvel et al. 1993; Kadowaki et al. 1996; Rocheleau et al. 1997). Once released into the extracellular milieu, Wnts interact with secreted proteins such as SFRPs and WIF (Kawano and Kypta 2003). In general, these factors are thought to function as inhibitors by sequestering Wnts and preventing their interaction with membrane-bound receptors. Other interaction partners include membraneanchored heparan sulfate proteoglycans (HSPGs). In Drosophila, the HSPG Dally acts as a positive regulator of Wnt activity, but its precise biochemical function is unknown (Tsuda et al. 1999).

Wnts activate responding cells by interacting with the seven-span transmembrane protein Frizzled $(\mathrm{Fz})$ and the single-span transmembrane protein LRP (Bhanot et al. 1996; Pinson et al. 2000; Tamai et al. 2000; Wehrli et al. 2000). Two functional complexes involving these proteins have been described. Wnts may simultaneously bind to Fz and LRP. This represents the initial step in the so-called canonical pathway, which leads to the formation of nuclear Tcf/ $\beta$-catenin complexes. Alternatively, when LRP is not expressed or down-modulated through 
secreted factors such as Dickkopfs (Bafico et al. 2001), Wnts may nonetheless form a complex with $\mathrm{Fz}$, triggering Tcf $/ \beta$-catenin-independent cellular responses such as increased calcium flux, repression of Tcf-mediated transcription, and cytoskeletal rearrangements. Collectively, these responses are often referred to as noncanonical signaling (Veeman et al. 2003). As of yet, this aspect of Wnt signaling has not been analyzed in the gut. For this reason, noncanonical Wnt signaling will not be covered in this review.

The key component of the Wnt canonical cascade is the cytoplasmic protein $\beta$-catenin. In the absence of Wnts, the scaffolding proteins APC and Axin/Axin2 sequester $\beta$-catenin allowing casein kinase I (CKI) to phosphorylate the $\mathrm{N}$ terminus of $\beta$-catenin at Ser S45, a residue often mutated in cancers (Amit et al. 2002; Liu et al. 2002). Subsequently, glycogen synthase kinase $3 \beta$ (GSK3 $\beta$ ) is recruited to phosphorylate additional serine and threonine residues $\mathrm{N}$-terminal to S45 (Rubinfeld et al. 1996). Phosphorylated $\beta$-catenin is then recognized by the F-box-containing protein $\beta$-TrCP, which mediates ubiquitination and proteosomal degradation of $\beta$-catenin (Hart et al. 1999; Kitagawa et al. 1999; Winston et al. 1999). Together, these proteins make up the so-called $\beta$-catenin destruction complex. As we shall see later, this complex plays a central role in the (de)regulation of intestinal homeostasis.

Under physiological conditions, continued destruction of $\beta$-catenin is interrupted following Wnt binding to Fz/ LRP. How the destruction complex senses Wnts at the cell surface is not fully understood. It has been assumed that the adapter protein Dsh through its association with $\mathrm{Fz}$ and the GSK3 $\beta$-binding protein, Frat, may participate in this process (Yost et al. 1998; Chen et al. 2003; Wong et al. 2003). Note, however, that recent genetic evidence excludes an essential requirement for Frat in Wnt signaling, since mice with deletions in all three Frat family members develop entirely normally (van Amerongen et al. 2005). In parallel, Wnts induce phosphorylation of the cytoplasmic tail of LRP, which allows docking of Axin to LRP (Tamai et al. 2004). Recruitment of Axin to the membrane is thought to disrupt the destruction complex, thereby releasing $\beta$-catenin. Lastly, it has been suggested that stabilization of $\beta$-catenin may be promoted by the protein phosphatase PP2A, which appears to dephosphorylate GSK3 $\beta$ substrates, including $\beta$-catenin (Yang et al. 2003).

Once released from the destruction complex, $\beta$ catenin translocates to the nucleus, where it associates with the Tcf family of transcription factors (Tcf1, Lef, Tcf3, and Tcf4) (Waterman 2004). Tcfs function by targeting $\beta$-catenin to specific DNA elements found in promoters and enhancers of target genes (Behrens et al. 1996; Molenaar et al. 1996). In turn, $\beta$-catenin recruits a number of nuclear factors responsible for transactivating Tcf target genes. Two of these factors include the histone acetylase CBP/p300 and the SWI/SNF component BRG1 (Hecht et al. 2000; Takemaru and Moon 2000; Barker et al. 2001). Activation of target genes also depends on the nuclear proteins Legless and Pygopus (Kramps et al.
2002; Parker et al. 2002; Thompson et al. 2002). It has been proposed that Legless and Pygopus are involved in directly activating transcription, possibly by recruiting chromatin remodeling factors. Legless and Pygopus may also function by transporting $\beta$-catenin to the nucleus (Townsley et al. 2004). Finally it is worth noting that in the absence of nuclear $\beta$-catenin or when nuclear $\beta$-catenin is sequestered by factors such as ICAT and Chibby (Tago et al. 2000; Takemaru et al. 2003), Tcfs associate with general transcriptional repressors such as Groucho (Cavallo et al. 1998; Roose et al. 1998). The latter silence target genes, in part, by recruiting histone deacetylases (HDACs), which render chromatin structure inaccessible to the basal transcriptional machinery. For an overview of the canonical Wnt pathway see Figure 1.

\section{Wnt signaling and the origin of intestinal epithelial cells}

The intestinal epithelium originates from embryonic endoderm, which in turn stems from pluripotent epiblast cells at the onset of gastrulation (embryonic day 6.0 [E6.0] in mice). During this stage, epiblast cells committed to form definitive endoderm ingress through the primitive streak displacing visceral endoderm. The first endodermal cells to travel through the primitive streak populate the anterior end of the embryo, whereas endoderm leaving at later stages colonizes more posterior regions. From E7.5 to E9.5, the endodermal lining covering the mesoderm and ectoderm undergoes a series of invaginations initiated at the anterior and posterior ends of the embryo, resulting in the formation of a proper gut tube (Fig. 2). At this stage, the primitive gut is composed of a uniform layer of cuboidal endodermal cells surrounded by splanchnic mesoderm. The intestine along with the other organs derived from endoderm only become morphologically evident during a patterning phase (E9.5E14.5) in which the primordial gut is subdivided and reshaped along the anterior-posterior axis (Fig. 2). For a thorough treatment of gut development see Wells and Melton (1999) and Roberts (2000).

The earliest role attributed to Wnt signaling during gut development was initially uncovered in ascidian embryos, where $\beta$-catenin was found to be essential for endoderm formation (Imai et al. 2000). Through gene targeting experiments, Kemler and colleagues (Lickert et al. 2002) showed that this function of $\beta$-catenin is evolutionarily conserved in mice. Ablation of $\beta$-catenin specifically in the node, notochord, and anterior primitive streak abrogated definitive endoderm formation. Moreover, analysis of chimeric embryos showed that $\beta$-catenin-mutant cells of the endodermal layer were unable to form endoderm but rather differentiated into precardiac mesoderm.

How $\beta$-catenin promotes definitive endoderm formation is unclear. Recent data have suggested that in endodermal cells, $\beta$-catenin may not necessarily act through Tcf factors. Indeed, Sinner et al. (2004) have proposed that in frogs, $\beta$-catenin drives the expression of endoderm-specific target genes by physically associating with 

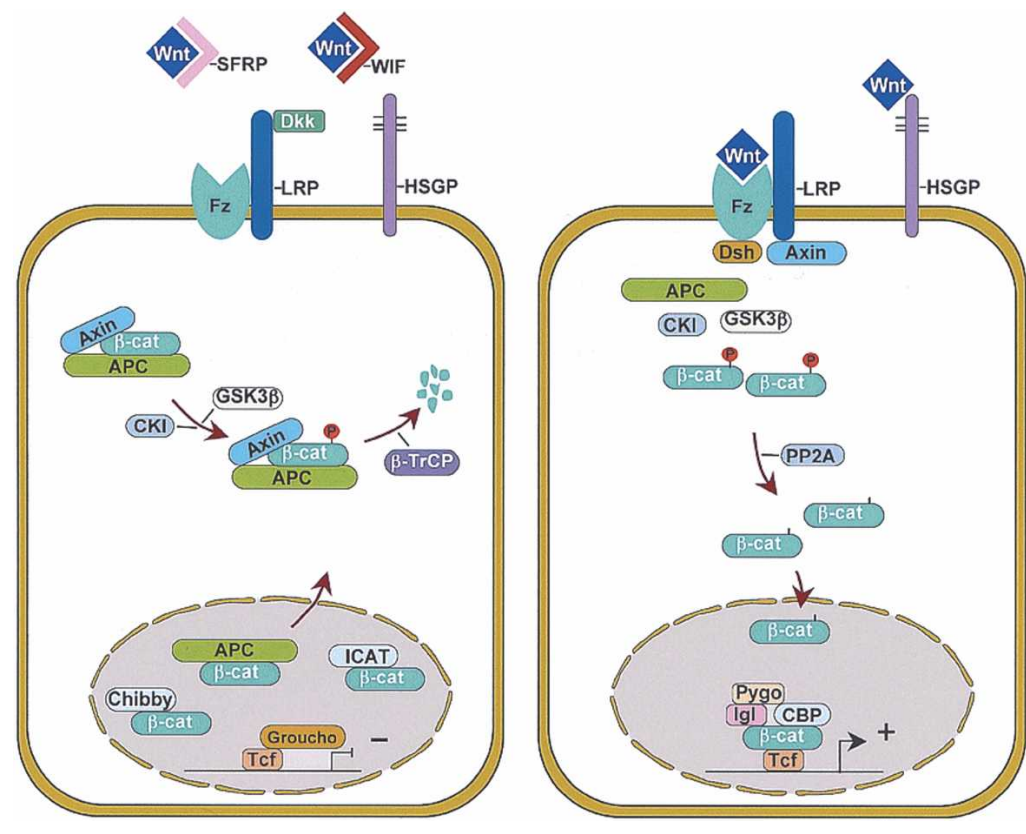

Figure 1. The Wnt canonical pathway. (Left) In the absence of Wnt stimulation, $\beta$-catenin levels are kept at a minimum through the destruction complex composed of APC, Axin, GSK3 $\beta$, and CKI. In the nucleus, Tcf factors associate with transcriptional repressors to block target gene activation. (Right) In the presence of Wnt stimulation, the destruction complex is destabilized, and $\beta$-catenin accumulates in the nucleus to activate transcription of Tcf target genes.
Sox17, an HMG box transcription factor, related to Tcfs. Given that in zebrafish and mice Sox17 also plays a role in the formation of definitive endoderm (Alexander and Stainier 1999; Kanai-Azuma et al. 2002), it will be interesting to test whether the Sox $17 / \beta$-catenin complex may represent a generalized mechanism for promoting endoderm specification. Another unanswered question raised by these findings regards the identity of the Wnt(s) stimulating $\beta$-catenin in the endoderm. In mice, Wnt 3 is a possible candidate, since in Wnt3-mutant embryos, the epiblast remains undifferentiated while the primitive streak does not form. Moreover, the expression of both mesodermal and definitive endodermal markers is abolished (Liu et al. 1999).

We have recently shown that Wnt signaling is required for gut tube formation (Gregorieff et al. 2004). During this stage (E8.5), in situ hybridization analysis revealed overlapping expression of Tcf 4 and Tcflin the hindgut. Simultaneous disruption of both genes led to severe defects in the formation of the hindgut and associated loss of expression of endodermal markers. This phenotype implies the existence of a Wnt source at the posterior end of the embryo, which would promote morphogenesis of the hindgut. A similar mechanism is utilized to drive posterior paraxial mesoderm and somite formation. In this case, Wnt3a expression in the presomitic mesoderm of the tailbud activates Lef and Tcf1 (Galceran et al. 1999). Anterior tube formation may also depend on the activity of Wnt signaling components. Analysis of APC hypomorphic mutant mice $\left(\mathrm{APC}^{\text {neoR}}\right)$ has shown that expression of APC in the endoderm is required for the involuting movements, which generate the foregut pocket (Fig. 2, AIP; Ishikawa et al. 2003). The foregut defects in APC hypomorphs may result from the increased $\beta$-catenin/Tcf transcriptional activity in endodermal cells or may be ascribed to an alternative role for APC in cell migration.
Our analysis of Tcf4/Tcf1 mutant embryos at later stages also revealed malformations of the gastrointestinal tract consistent with both factors playing a role in patterning the gut (Gregorieff et al. 2004). As could be expected from the early defects in hindgut formation, the intestine of $\mathrm{Tcf} 4^{-/-} / \mathrm{Tcf}^{-/-}$embryos is severely truncated. However, closer inspection uncovered anterior transformations at the stomach-duodenal junction. Expression analysis using specific markers of stomach and intestine revealed duplications of the stomach, suggesting that Tcf4 and Tcf1 promote an "intestinal" fate within the primitive gut, and in their absence more anterior regions of the gut are expanded. Evidence supporting this interpretation was recently provided by Hogan and coworkers (Okubo and Hogan 2004), who showed that when a constitutively active form of $\beta$-catenin is misexpressed in the lung endoderm, these cells turn on genes normally restricted to the intestine, implying once again that Wnt signals instruct endodermal cells to become intestine as opposed to other endodermal lineages.

\section{Wnt signaling and adult intestinal homeostasis}

Once the basic structure of the intestinal tract is laid out, differentiation along the radial axis may take place (Figs. 2, 3). During this process the epithelium of the small intestine is remodeled to form characteristic finger-like projections (villi) and deep invaginations termed crypts. Similar events take place in the colon, where crypts form but a flat surface epithelium exists instead of villi. These events coincide with the compartmentalization and cyto-differentiation of the epithelium. The intervillus regions of the fetal intestine, which are replaced by crypts in the first weeks after birth, are lined with highly proliferative progenitor cells. These transit-amplifying cells give rise to two differentiated cell lineages (i.e., the absorbtive enterocytes and secretory cells). The 
Figure 2. Time line of intestinal development in the mouse. Definitive endodermal cells are specified at E6.0 during gastrulation. The left panel shows the bottom view of an E8.5 embryo, along with a schematic representation of the primitive gut. At E8.5 endodermal tube formation is initiated by folding (depicted by arrows) of the endodermal lining at the anterior and posterior ends creating anterior and caudal intestinal portals (AIP and CIP). The endodermal lining is stained with a probe recognizing Foxa1. At later stages (E9.5-E14.5), the primitive gut tube is patterned along the anteriorposterior axis. The expression of specific intestinal markers first appears in the hindgut at E9.0 (Maunoury et al. 1992; Braunstein et al. 2002). The middle panel shows a whole mount preparation of the entire gastro-intestinal tract (E12.5) stained for the intestinal marker Villin. Villus formation and cyto differentiation (formation of enterocytes, goblet cells, enteroendocrine cells and Paneth cells) is initiated at E14.5. In the right panel, sections from the small intestine were stained for the proliferation marker Ki67. Mutations associated with the Wnt pathway affect gut development at various stages (see text). Figure adapted and reprinted, with permission, from Wells and Melton (@) 1999 by Annual Reviews http://www.annualreviews.org).

secretory lineage can be further subdivided into mucussecreting goblet cells, hormone-secreting enteroendocrine cells, and bactericidal Paneth cells. Maturation of progenitor cells coincides with upward migration. Upon reaching the tips of the villi or the surface epithelium of the colon, the differentiated cells undergo apoptosis and are shed into the lumen. One exception to this rule is the Paneth cell, which is generated from a progenitor migrating downward toward the crypt base. The self-renewing capacity of the intestine depends on the existence of stem cells (Marshman et al. 2002; Pinto and Clevers 2005). Classical labeling experiments have shown that in the small intestine stem cells reside just above the Paneth cell compartment, while in the colon they occupy the first cell position at the crypt bottom.

There are now several lines of in vivo evidence that show that normal proliferation of the transit-amplifying cells is entirely dependent on continual stimulation of the Wnt pathway. First, removal of Tcf $4, \beta$-catenin, or overexpression of the Wnt inhibitor Dkk-1 results in a severe loss of proliferative epithelial cells in both the fetal and adult intestine (Korinek et al. 1998; Pinto et al. 2003; Ireland et al. 2004; Kuhnert et al. 2004). Cell cycle arrest is also observed in CRC cell lines in which $\beta$-catenin/Tcf activity is blocked either through expression of dominant-negative Tcf4 or knockdown of $\beta$-catenin (van de Wetering et al. 2002, 2003). Consistent with these results, mutations in the negative regulator of Wnt signaling APC, or overexpression of oncogenic forms of $\beta$-catenin result in hyperproliferation of the epithelium (Nagase and Nakamura 1993; Oshima et al. 1995; Kinzler and Vogelstein 1996; Sansom et al. 2004). Lastly, progenitors located at the bottom of the crypts accumulate nuclear $\beta$-catenin, implying that these cells respond to Wnt stimulation (van de Wetering et al. 2002). Although these studies confirm the strong link between Wnt signaling and maintenance of transit-amplifying cells, it should be noted that virtually no evidence exists to draw a similar link between Wnt signals and stem cells (Fig. 3). Part of the difficulty in tackling this issue is related to our lack of reliable markers of intestinal stem cells. In addition to proliferation, we may also consider the accumulating evidence implying an additional function for Wnt signaling in driving the differentiation of secretory lineages. Indeed, blocking active Wnt signaling in vivo results in a reduction or absence of goblet, enteroendocrine, and Paneth cells, while enterocytes appear spared (Korinek et al. 1998; Pinto et al. 2003; Ireland et al. 2004).

Supported by these findings, a model can be proposed whereby transit-amplifying cells responding to a source of Wnts at the crypt bottom proliferate and concomitantly commit themselves to the secretory lineage. As these progenitors move up the crypt and further away from the Wnt source, Tcf $/ \beta$-catenin activity is turned off, thus favoring cell cycle arrest and terminal differentiation. This simplistic view overlooks a number of issues. In our discussion below, we shall highlight four major questions: What is the genetic program regulated by Tcf/ $\beta$-catenin in crypt progenitors? Where and what is the Wnt source? How does Wnt signaling regulate secretory cell lineage commitment? And, finally, how is Wnt signaling turned off?

\section{Tcf/ß-catenin target genes}

Most studies aimed at identifying Tcf $/ \beta$-catenin target genes (for simplicity the term target gene here refers to either direct or indirect Wnt-responsive genes) in intestinal cells have made use of systems in which $\beta$-catenin is constitutively activated such as in CRC cell lines (see Table 1 for a selected list of Tcf target genes). Consequently, as we shall see later, the majority of Tcf $/ \beta$ catenin target genes have been associated with various 


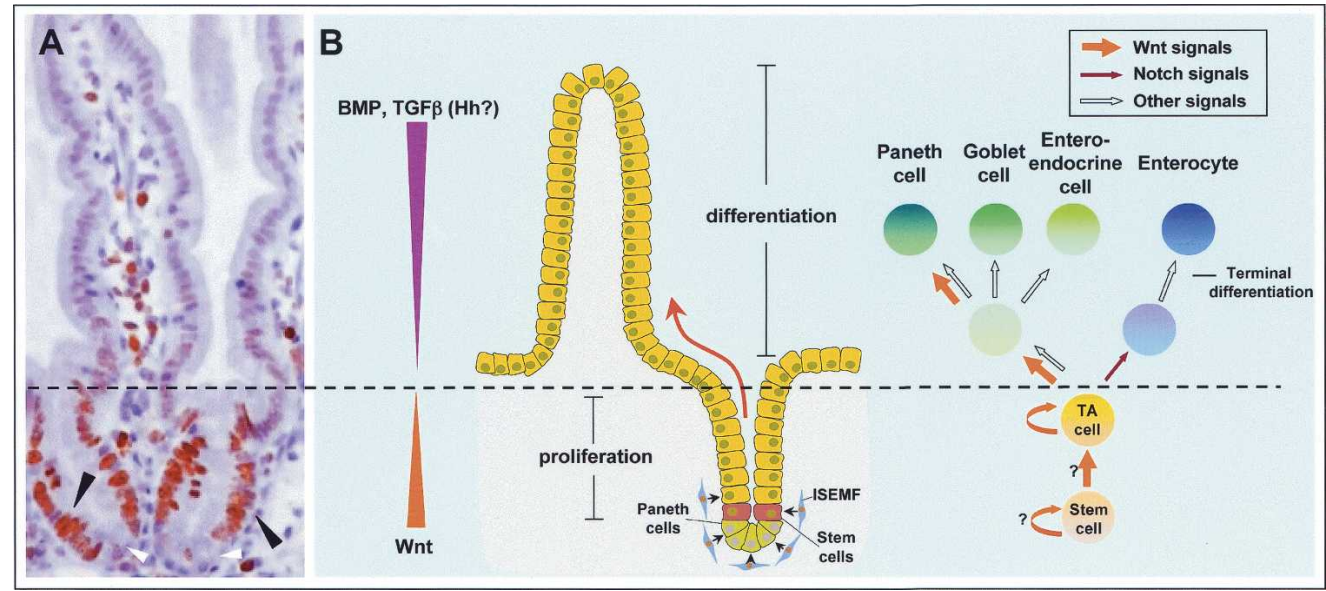

Figure 3. Adult intestinal homeostasis. $(A, B)$ Schematic representation and section of the crypt-villus unit in the mature small intestine. Proliferative cells reside in the crypts, while differentiated cells occupy the villus. Crypt progenitors migrate up (red arrow) the crypt-villus axis before shedding into the lumen. The process of epithelial renewal takes 3-6 d and is ensured by a small number of asymmetrically dividing stem cells at the bottom of the crypts. Wnt signaling in the adult intestine promotes proliferation of progenitor or transit-amplifying (TA) cells, as well as commitment toward secretory lineages. Wnt signaling may also drive terminal differentiation of certain secretory lineages (see text). Although it is commonly believed that Wnt signaling may promote proliferation and/or differentiation of intestinal stem cells, there is no evidence that formally proves this (see arrows with question marks). In panel $A$, black arrowheads indicate Ki67 positive transit-amplifying cells, while white arrowheads indicate the Paneth cell compartment.

processes important for tumorigenesis (i.e., cellular proliferation, survival, and motility). Given that many of these genes are also expressed in normal crypt progenitor cells (van de Wetering et al. 2002), efforts are now being undertaken, through classical loss- or gain-of-function experiments in mice, to test their function during intestinal development and homeostasis. So far, however, only a limited number Tcf $/ \beta$-catenin targets have been tested in vivo.

The proliferative effects of Wnt signaling on crypt progenitors have, for some time now, been linked to cell cycle regulators such as c-Myc and cyclin D1 (He et al. 1998; Shtutman et al. 1999; Tetsu and McCormick 1999|. Both factors are overexpressed in colorectal tumors, and blocking expression of either gene inhibits proliferation in CRC cell lines (Arber et al. 1997; van de Wetering et al. 2002; Wong and Pignatelli 2002). However, cyclin D1 null mice do not appear to exhibit any abnormalities in the intestine, other than a modest reduction in the propensity to develop polyps when crossed with the APC ${ }^{\text {min }}$ mice (Hulit et al. 2004). This observation suggests that other cyclin Ds may be more relevant downstream $\beta$-catenin/Tcf target genes. Along these lines, our own observations have shown that cyclin D2 is an early downstream Tcf4 target in the fetal gut (A. Gregorieff and H. Clevers, unpubl.). Moreover, microarray studies have shown that cyclin D1 levels do not appear to be affected when conditionally deleting APC (Sansom et al. 2004). C-Myc has been confirmed as a Tcf/ß-catenin target in vivo (van de Wetering et al. 2002; Pinto et al. 2003), although its precise function in normal epithelial cells remains to be clarified. In the bone marrow, recent evidence suggests that $\mathrm{c}-\mathrm{Myc}$ promotes the release of hemopoietic stem cells from the stem cell niche by regulating the expression levels of adhesion molecules (Wilson et al. 1997). In the skin, ectopic expression of c-Myc diverts epidermal stem cells to a sebaceous gland fate at the expense of hair follicles (Braun et al. 2003). Whether c-Myc performs similar functions in the intestine will need to be examined by a conditional knockout approach.

Another Tcf/ $\beta$-catenin target gene, which has been implicated in promoting proliferation is Id2 (Rockman et al. 2001; van de Wetering et al. 2002). The Id proteins represent a family of naturally occurring inhibitors of basic helix-loop-helix transcription (bHLH) factors, and function in many circumstances to prevent differentiation (Ruzinova and Benezra 2003). In particular, Id2 is highly abundant in several cancer types, and when forcibly expressed in colon cancer cell lines, Id2 has been shown to increase anchorage-independent survival (Rockman et al. 2001). Recent in vivo evidence, on the contrary, suggests that Id 2 may have a completely different role in crypt progenitor cells (Russell et al. 2004). In the Id2 knockout intestines, differentiation of endoderm is impaired during the late fetal stages (E18.5). Consequently the villi in several areas appear replaced by multilayered, undifferentiated endoderm. These areas of pseudostratified epithelium later develop into dysplastic and metaplastic tumors exhibiting high levels of nuclear $\beta$-catenin. Interestingly, these lesions also show a loss of Paneth cells and enteroendocrine cells and increased numbers of Goblet cells.

Expression profiling has also identified genes implicated in many other processes in addition to the control of proliferation and/or differentiation. The tyrosine kinase receptors EphB2 and EphB3 and their ligand ephrin B1 illustrate this point (Batlle et al. 2002). Consistent with their well-known roles in cell sorting in various tissues, these receptor/ligands pairs are expressed in an 
Table 1. List of $\beta$-catenin/Tcf target genes tested functionally in vitro or in vivo

\begin{tabular}{|c|c|c|c|}
\hline Gene & Type & LOF/GOF & References \\
\hline c-Myc & -bHLH transcription factor & -knockdown blocks proliferation & $\begin{array}{l}\text { He et al. 1998; van de Wetering et } \\
\text { al. } 2002\end{array}$ \\
\hline Cyclin D1 & -cell cycle regulator & $\begin{array}{l}\text {-cyclinD1 } 1^{-/-} / \mathrm{APC}^{\mathrm{min} /+} \text { show } \\
\text { reduced polyp burden }\end{array}$ & $\begin{array}{l}\text { Shtutman et al. 1999; Tetsu and } \\
\text { McCormick 1999; Hulit et al. } \\
2004\end{array}$ \\
\hline $\mathrm{Id} 2$ & $\begin{array}{l}\text {-inhibitor of bHLH transcription } \\
\text { factors }\end{array}$ & $\begin{array}{l}\text {-Id } 2^{-/-} \text {develop tumors and show } \\
\text { impaired differentiation }\end{array}$ & $\begin{array}{l}\text { Rockman et al. 2001; Russell et al. } \\
2004\end{array}$ \\
\hline ITF-2 & -bHLH transcription factor & $\begin{array}{l}\text {-overexpression promotes } \\
\text { neoplastic transformation }\end{array}$ & Kolligs et al. 2002 \\
\hline Tcfl & -Wnt signaling & $\begin{array}{l}-\mathrm{Tcfl}^{-1-} / \mathrm{APC}^{\mathrm{min} /+} \text { show increased } \\
\text { polyp burden }\end{array}$ & Roose et al. 1999 \\
\hline PPAR $\delta$ & $\begin{array}{l}\text {-ligand-activated transcription } \\
\text { factors }\end{array}$ & $\begin{array}{l}\text {-PPAR } \delta^{-/-} / \mathrm{APC}^{\mathrm{min} /+} \text { show } \\
\text { increased polyp burden } \\
\text {-treatment with PPAR } \delta \text { agonist, } \\
\text { GW501516, increases number } \\
\text { and size of polyps in APC }\end{array}$ & $\begin{array}{l}\text { He et al. 1999; Gupta et al. 2004; } \\
\text { Harman et al. 2004; Reed et al. } \\
2004\end{array}$ \\
\hline COX-2 & -prostaglandin pathway & $\begin{array}{l}-\mathrm{COX}-2^{-/-} / \mathrm{APC}^{\Delta 716 /+} \text { show reduced } \\
\text { polyp burden }\end{array}$ & $\begin{array}{l}\text { Oshima et al. 1996; Hsi et al. } \\
\text { 1999; Araki et al. } 2003\end{array}$ \\
\hline HDAC2 & -histone deactylase & $\begin{array}{l}\text {-treatment with HDAC2 inhibitor, } \\
\text { valproic acid, reduces polyp } \\
\text { number in } \mathrm{APC}^{\text {min } /+} \text { mice }\end{array}$ & Zhu et al. 2004 \\
\hline FGF18 & -growth factor & $\begin{array}{l}\text {-knockdown suppresses growth of } \\
\text { CRC cells }\end{array}$ & Shimokawa et al. 2003 \\
\hline FGF20 & -growth factor & $\begin{array}{l}\text {-knockdown suppresses } \\
\text { anchorage-independent growth }\end{array}$ & Chamorro et al. 2005 \\
\hline Endothelin & -growth factor & $\begin{array}{l}\text {-rescues growth arrest and } \\
\text { apoptosis resulting from } \\
\text { blocking } \beta \text {-catenin }\end{array}$ & Kim et al. 2005 \\
\hline Gastrin & $\begin{array}{l}\text {-gastrointestinal growth factor } \\
\text { and hormone }\end{array}$ & $\begin{array}{l}\text {-Gastrin }{ }^{-/-} / \mathrm{APC}^{\mathrm{min} /+} \text { show reduced } \\
\text { polyp burden }\end{array}$ & Koh et al. 2000 \\
\hline BAMBI & $\begin{array}{l}\text {-BMP and activin } \\
\text { membrane-bound inhibitor }\end{array}$ & $\begin{array}{l}\text {-overexpression blocks } \\
\text { TGF } \beta \text {-mediated growth } \\
\text { inhibition }\end{array}$ & Sekiya et al. 2004 \\
\hline MMP7/Matrilysin & -ECM protease & $\begin{array}{l}-\mathrm{MMP}^{-/-} / \mathrm{APC}^{\mathrm{min} /+} \text { show reduced } \\
\text { polyp burden }\end{array}$ & Wilson et al. 1997 \\
\hline Nr-CAM & -adhesion & $\begin{array}{l}\text {-overexpression increases cellular } \\
\text { motility }\end{array}$ & Conacci-Sorrell et al. 2002 \\
\hline Mdr1 & $-\mathrm{ABC}$ transporter & $\begin{array}{l}-\mathrm{Mdr}^{-/-} / \mathrm{APC}^{\mathrm{min} /+} \text { show reduced } \\
\text { polyp burden }\end{array}$ & Yamada et al. 2000, 2003 \\
\hline ENC1 & $\begin{array}{l}\text {-BTB/Kelch protein family } \\
\text { member }\end{array}$ & $\begin{array}{l}\text {-overexpression increases growth } \\
\text { rate in CRC cells }\end{array}$ & Fujita et al. 2001 \\
\hline APCDD1 & -unknown & $\begin{array}{l}\text {-knockdown inhibits cell/tumor } \\
\text { growth }\end{array}$ & Takahashi et al. 2002 \\
\hline
\end{tabular}

inverse gradient along the crypt-villus axis, with EphB2 and EphB3 high in crypt cells and their ligand ephrin-B1 predominating in the villi. This expression pattern is tightly regulated both in vitro and in vivo by Tcf/ $\beta$ catenin. In vivo confirmation of the importance of these molecules came from the analysis of EphB2 $2^{-/-} \mathrm{B} 3^{-/-} \mathrm{KO}$. In these mice, proliferative and differentiated cell populations intermingle. Furthermore, in EphB3 ${ }^{-/-}$mice, Paneth cells no longer home to the crypt bottom but rather scatter along crypts and villi. Thus, a Wnt signaling gradient controls cell positioning along the crypt-villus axis through regulation of EphB2 and EphB3 gene expression.

The functional characterization of Tcf $/ \beta$-catenin target genes will continue to be a major focus of interest for the coming years. We shall return to this issue in the context of colon carcinogenesis.

\section{The Wnt source}

The exact location or identity of the Wnts that drive proliferation is unclear. Nevertheless it is believed that mesenchymal cells or, more specifically, intestinal subepithelial myofibroblasts (ISEMFs), immediately adjacent to crypt epithelial cells, are a source of Wnts (Bienz and Clevers 2000; Madison et al. 2005). This notion is based in part on classic coculture experiments, which have shown that these cells are able to simulate proliferation of epithelial cells (Powell et al. 1999) We recently tested this hypothesis by screening all 19 Wnts for expression in the adult intestine (A. Gregorieff and H. Clevers, in prep.). Through this approach we found several Wnts expressed in crypt epithelial cells, but so far none were detected in ISEMFs. Ablation of the Wnt 
genes associated with crypt epithelial cells will be required to test their function. Until then, if we are to assume that these Wnts drive proliferation, then the next obvious question is what regulates Wnt expression in the epithelium. Here, once again, we may have to turn to ISEMFs. These cells are known to produce paracrine growth factors (Fritsch et al. 2002), which conceivably could activate Wnt gene expression in the epithelium. This idea however remains speculative.

On a related issue, genetic evidence in mice has identified two transcription factors, FoxL1 and Nkx2.3, involved in regulating growth signals emanating from the mesenchyme (Kaestner et al. 1997; Pabst et al. 1999; Perreault et al. 2005). Deletion of either gene in mesenchymal cells results in increased epithelial proliferation, suggesting that FoxL1 and Nkx2.3 normally play an inhibitory role. Kaestner and colleagues (Perreault et al. 2001) observed up-regulation of the HSPGs Syndecan1 and Perlecan in FoxL1 $1^{-/-}$mice. Although HSPGs have been implicated in stimulating Wnt signals (Tsuda et al. 1999; Perreault et al. 2001), it remains to be tested whether these changes are a cause or an effect of the increased proliferation.

\section{Cell lineage commitment}

The disproportionate reduction in goblet, enteroendocrine, and Paneth cell numbers, resulting from the ablation of Wnt signals, suggests a definite role for Wnts in specifying secretory lineages. Recently, some general rules for cell lineage commitment in the intestine have been uncovered. Precursors of all three secretory cell types express the bHLH factor MATH1. Accordingly, MATH1 deficient mice lack goblet, enteroendocrine, and Paneth cells but do produce enterocytes (Yang et al. 2001). The latter cells derive from progenitors expressing Hes1, based on the fact that Hes1 $1^{-1-}$ intestines display increased numbers of secretory cells at the expense of enterocytes (Jensen et al. 2000). Interestingly, Hes1 transcription is activated by Notch signaling in other biological models (Ohtsuka et al. 1999), while Hes1 transcriptionally represses MATH1 expression (Jensen et al. 2000; Zheng et al. 2000). Together these findings suggest a model whereby commitment toward the enterocyte lineage would be favored in cells with active Notch signaling, turning on Hes1 transcription. Inversely, in the absence of Notch signaling, MATH1 would be upregulated skewing the cells toward secretory lineages (Fig. 3B).

Further commitment toward specific cell types depends on yet other transcription factors. For example, the activation of NGN3, BETA2, Pax4, and Pax6 is associated with enteroendocrine (sub)lineages (Schonhoff et al. 2004), while differentiation of goblet cells is influenced by KLF4 (Katz et al. 2002). Moreover, in $\mathrm{ELF3}^{-/-}$ mice differentiation of absorptive and goblet cells is impaired (Ng et al. 2002).

The connection between Wnt signaling and any of these factors remains an open question. One putative link was suggested by the observation, as we have mentioned earlier, that ablation of the Wnt target gene and
bHLH antagonist Id2 results in impaired production of secretory lineages (Russell et al. 2004). It is plausible that Id2 may mediate these effects by directly antagonizing the activity of certain bHLH transcription factors such as MATH1. Alternatively, Wnt signals may directly activate the expression of genes involved in cell lineage commitment. Although no evidence for this exists so far, expression profiling of mouse models displaying impaired Wnt signaling suggests that the final stages of maturation of secretory lineages may depend on active Wnts signals. In particular, we and others find that the expression of Paneth cell markers, such as antimicrobial peptides (i.e., cryptdins and defensins), are directly stimulated by $\beta$-catenin/Tcf (Andreu et al. 2005; van Es et al. 2005).

\section{Counteracting Wnt signaling}

There are two nonmutually exclusive mechanisms that could explain how the stimulatory effects of the Wnt cascade are turned off in the intestine. In one scenario, activation of Wnt signals would gradually and passively dissipate as progenitors migrate up along the crypt-villi axis in sites where canonical Wnts are limiting. On the other hand, a more active mechanism may be utilized, involving "negative" cross-talk between the Wnt pathway and other signaling pathways. As we shall discuss below, the TGF $\beta$ and BMP cascades are associated with growth inhibition in the gut and thus may represent examples of Wnt-counteracting pathways.

TGF $\beta$ signaling components are localized in differentiated epithelial cells, where they have well-documented growth suppressive effects (Sancho et al. 2004). Furthermore, in both man and mouse, benign adenomas acquire invasive properties following the acquisition of inactivating mutations in the TGF $\beta$-RII receptor or the intracellular signaling components Smad2 and Smad4 (Markowitz et al. 1995; Eppert et al. 1996; Takagi et al. 1996). Mice with germline mutations in Smad3 and the latent TGFß-binding protein 4 (LTBP-4) also develop colorectal cancer (Zhu et al. 1998; Sterner-Kock et al. 2002). Several groups have described mechanisms by which TGF $\beta$ signals could antagonize Wnt signaling in the intestine. One possible route may involve the alternative TGF $\beta$ effector and MAPKKK, TAKI. In Caenorhabditis elegans and mammalian cells, activation of TAK1 stimulates the activity of the MAPK NLK, which in turn, down-regulates Tcf (Ishitani et al. 1999; Meneghini et al. 1999). Alternatively, Sasaki et al. (2003) have shown that TGF $\beta$ stimulation inhibits Tcf $4 / \beta$-catenin transactivation of cMyc via the ability of Smad3 to physically interact with $\beta$-catenin and thereby decouple Tcf $4 / \beta$-catenin complexes.

Similar inhibitory functions have been attributed to BMPs. BMP2 and BMP4 are expressed in mature epithelial cells and villus mesenchyme, respectively. Moreover, both factors appear to activate their downstream signaling components SMAD1, SMAD5, and SMAD8 in the differentiated epithelium (Haramis et al. 2004; Hardwick et al. 2004). Patients harboring mutations in BMP 
signaling components suffer from juvenile polyposis syndrome (JPS), which is characterized by the formation of hamartomatous polyps throughout the gastrointestinal tract (Howe et al. 2001, 2004; Zhou et al. 2001). Similar polyps are formed in the stomach and duodenum of Smad4 heterozygous mice. Insight into how these defects occur was recently provided by the generation of transgenic mice expressing the BMP inhibitor Noggin in the intestinal epithelium (Haramis et al. 2004) and in mice in which the BMPR1A gene was conditionally deleted in the intestinal epithelium (He et al. 2004). In both cases, these mice develop lesions equivalent to those found in JPS. At the earliest stages in the development of these lesions, BMP inhibition results in de novo crypt formation combined with increased numbers of proliferative cells in normally differentiated compartments of the villi. Based on these observations, it appears that BMP signaling may restrict ectopic Wnt-mediated proliferation in the differentiated epithelial cells and thereby confine crypt formation to regions immediately adjacent to the muscularis. How BMPs would antagonize Wnt signaling in the intestine still remains to be clarified. However, a tentative model has been proposed by He et al. (2004), in which BMP4 somehow promotes PTEN activation in intestinal stem cells, which in turn would repress $\beta$-catenin/Tcf activity through the PI3 kinase-AKT pathway. These results await further confirmation.

Another class of signaling molecule, which may oppose the effects of Wnt signaling in the intestine are the Hedgehogs (Hh). The available evidence supporting such a role is somewhat conflicting. During chick and mouse development Sonic hedgehog (Shh) and Indian hedgehog (Ihh) play multiple roles in patterning of the gastrointestinal tract (Apelqvist et al. 1997; Litingtung et al. 1998; Ramalho-Santos et al. 2000; Sukegawa et al. 2000; Fukuda et al. 2003). Both proteins have been implicated in the growth of upper-digestive tract tumors (Berman et al. 2003; Thayer et al. 2003). Van den Brink et al. (2004) examined the role of Ihh signaling in the colonic epithelium. In the human colon, Ihh is uniquely expressed among nonproliferative cells of the surface epithelium. Accordingly, rats treated with cyclopamine, a smallmolecule inhibitor of $\mathrm{Hh}$ signaling, displayed defects in enterocyte differentiation and an increase in the number of cycling cells per crypt. These investigators also showed that Ihh signaling in vitro interferes directly with $\beta$-catenin/Tcf transcriptional activity (Van den Brink et al. 2004). More recently, ectopic epithelial proliferation was also reported in mice transgenically expressing the pan-Hh inhibitor HIP in the intestinal epithelium (Madison et al. 2005). However, ablation of Hhs in mice by homologous recombination contradicts these results (Ramalho-Santos et al. 2000). Ihh deficient mice display a loss of enteric neurons and as a result develop dilated colons reminiscent of Hirschprung's disease, while in the small intestine, the number of cycling epithelial cells is reduced. Shh mutant mice show intestinal metaplasia in the stomach and duodenal stenosis.

\section{Wnt signaling in colorectal cancer}

In humans, sporadic and hereditary forms of colorectal cancer develop along a well-defined sequence of histopathological changes (Fearon and Vogelstein 1990). The earliest lesions occurring in the colonic epitheliumaberrant crypt foci (ACF) - are characterized by dysplastic or hyperplastic crypts. Subsequent expansion of the ACF generates larger adenomas, which in turn may progress to carcinoma in situ and invasive adenocarcinomas. Because these lesions are easily identifiable, researchers have been able to characterize the genetic alterations associated with each stage (Fearon and Vogelstein 1990; Sancho et al. 2004). The earliest mutations identified in the adenoma-to-carcinoma sequence alter the function of components of the Wnt pathway. Mutations in APC are responsible for an inherited form of CRC, termed familial adenomatous polyposis (FAP) (Groden et al. 1991; Kinzler et al. 1991). Moreover, the overwhelming majority (80\%) of early adenomas from sporadic cases of CRC bear truncating mutations in APC (Nagase and Nakamura 1993). Some of the remaining cases of CRC result from mutations in $\beta$-catenin, and Axin2 (Ilyas et al. 1997; Morin et al. 1997; Liu et al. 2000). Below we shall discuss how activating mutations in the Wnt cascade confer upon cells a selective growth advantage, which allows for the initial expansion of the precancerous lesion.

\section{Consequences of hyperactive Wnt signaling}

The immediate consequences of mutations in APC and $\beta$-catenin are well understood. $\beta$-Catenin mutations disrupt the CK1/GSK3 $\beta$ phosphorylation sites at the $\mathrm{N}$ terminus of the protein (Ilyas et al. 1997; Morin et al. 1997). Consequently, mutant $\beta$-catenin is no longer recognized by $\beta$-TrCP and becomes stabilized. In turn, mutant $\beta$-catenin is free to enter the nucleus and constitutively activate transcription through Tcfs. Equivalent effects result from APC inactivation. Truncation of APC removes repetitive elements within the protein responsible for binding to $\beta$-catenin and Axin (Nathke 2004). As a result, GSK3 $\beta$ phosphorylation and subsequent degradation of $\beta$-catenin is severely impaired. Frameshift mutations in Axin2 eliminate its DIX domain required for homo-oligomerization. Although expression of mutant Axin 2 in cells results in increased $\beta$-catenin accumulation, it is unknown how mutant Axin2 interferes with the destruction complex (Liu et al. 2000).

In addition to affecting the function of the destruction complex, mutations in APC have been proposed to disrupt its ability to regulate $\beta$-catenin function in the nucleus (Fabbro and Henderson 2003; Nathke 2004). For example, APC contains both nuclear export and import signals, which allow it to act as a nuclear-cytoplasmic shuttle. Once in the nucleus APC promotes export of $\beta$-catenin and thereby deactivation of Tcf-mediated transcription, a property lost by mutation of APC (Henderson 2000; Rosin-Arbesfeld et al. 2003). Alternatively, by associating with the transcriptional repressor CtBP, APC 
may also interfere with the formation of $\beta$-catenin/Tcf complexes (Hamada and Bienz 2004). Whether these additional pathways regulating $\beta$-catenin activity play a significant role in neoplastic transformation remains to be determined.

How does constitutive $\beta$-catenin/Tcf transcriptional activity promote adenoma formation? As we first discussed in the context of homeostasis, the Wnt pathway normally promotes proliferation of progenitor cells. It is silenced when these cells exit the crypt compartment. In general terms, we may say that adenomas result from the unabated expansion of cells, which have adopted a crypt progenitor-phenotype. Consequently, the genes activated by aberrant $\beta$-catenin/Tcf activity in CRC cells simply reflect the normal genetic program of crypt progenitors (van de Wetering et al. 2002). The identity and function of these target genes has been a hot topic in recent years. Today, the number of candidate $\beta$-catenin/ Tcf effector genes has exploded and includes genes that may intervene in the cell cycle (c-myc, cyclinD1), tumor cell migration (e.g., MMPs, Nr-CAM) (Wilson et al. 1997; Conacci-Sorrell et al. 2002), survival (e.g., Survivin) (Zhang et al. 2001), and growth (e.g., FGF18, Gastrin) (Koh et al. 2000; Shimokawa et al. 2003), as well as angiogenesis (VEGF) (Easwaran et al. 2003) and prostaglandin signaling (e.g., COX-2, PPARס) (He et al. 1999; Hsi et al. 1999; Araki et al. 2003). A complete description of all putative Tcf target genes identified so far would be well beyond the scope of this review. Instead we refer the reader to Table 1, which highlights target genes that have been tested functionally in CRC cells.

Of particular relevance to this review is the observation that aberrant $\beta$-catenin/Tcf activity also leads to transcriptional up-regulation of components of the Wnt signaling pathway proper. In colon cancer cells, both Tcf1 and Lef are strongly up-regulated through direct activation by Tcf4. Genetic evidence in mice has shown that Tcf1 acts as tumor suppressor (Roose et al. 1999). Tcf1 knockout mice display a predisposition toward developing spontaneous intestinal adenomas, and polyp counts are greatly increased in $\mathrm{APC}^{\mathrm{min} /+}$ mice lacking Tcf1. One untested hypothesis put forward to explain these results is the suggestion that in colon cancer cells Tcf4 promotes expression of dominant-negative isoforms of Tcf1, lacking the $\beta$-catenin interaction domain. As such, activation of Tcf1 expression would constitute a negative feedback loop involved in inhibiting high levels of $\beta$-catenin/Tcf activity. The effects of up-regulating Lef in tumor cells have not been tested in vivo. However, Lef is likely to play a positive role in tumorigenesis based on the observation that Tcf4 specifically activates transcription of full-length Lef isoforms capable of interacting with $\beta$-catenin (Hovanes et al. 2001). In addition, Lef has been shown to harbor distinct biochemical properties when compared to Tcf4. For instance, Lef, contrary to Tcf4, appears to be refractory to the inhibitory effects of a TGF $\beta-S m a d 3$ pathway (Sasaki et al. 2003).

Another $\beta$-catenin/Tcf target gene and Wnt signaling component relevant to cancer is Axin2. In normal cells, as part of a negative feedback mechanism, Axin2 is up- regulated following Wnt stimulation (Jho et al. 2002; Leung et al. 2002; Lustig et al. 2002). As we have described earlier, this apparently attenuates excessive Wnt stimulation since inactivating mutations in Axin2 promote tumorigenesis. Up-regulating Axin2 in adenomas may also serve to suppress the effects of aberrant $\beta$-catenin signaling. This idea is supported by the finding that overexpression of Axin in CRC cell lines bearing mutations in APC (but not $\beta$-catenin) down-regulates $\beta$-catenin levels (Hart et al. 1998). The significance of these observations awaits further in vivo confirmation.

New players in Wnt pathway-driven colorectal cancer?

Given the predominant role of the Wnt pathway in CRC and many other types of cancer, several laboratories have shifted their attention on other Wnt signaling components in addition to the usual culprits such as APC and $\beta$-catenin. Recently, two groups have documented, in a high percentage of human colorectal adenomas and aberrant crypt foci, epigenetic silencing of the genes encoding for SFRPs (Caldwell et al. 2004; Suzuki et al. 2004). Suzuki et al. (2004) followed up on these initial observations by testing the impact of expressing SFRPs in CRC cell lines. Transfection of SFRP1, SFRP2, and SFRP5 in HCT 116 and SW480 cells decreased $\beta$-catenin levels, and transcriptional activity and resulted in growth inhibition and apoptosis. However, in similar experiments performed by Bafico et al. (2004), SFRP1 only had inhibitory effects on engineered HCT 116 cells containing a single wild-type $\beta$-catenin allele, whereas parental HCT116 cells with both wild-type and mutant alleles or HCT116 cells containing only a mutant allele were insensitive to SFRP1. Despite these discrepancies both groups show that HCT116 produce several Wnts and that treatment with SFRPs blocks autocrine Wnt-induced proliferation. Taking into account the results from Bafico et al. (2004), it is more likely that silencing of SFRPs would only provide a growth advantage before mutations in APC and $\beta$-catenin have occurred. At later stages of tumorigenesis when cancer cells constitutively express high levels of $\beta$-catenin, disrupting Wnt function would most likely be inconsequential.

\section{Concluding remarks}

As we have highlighted in this article, the intestinal epithelium provides an attractive system to study how Wnt signaling regulates cellular growth and differentiation. Current evidence validates the Wnt cascade-in particular the $\beta$-catenin/Tcf4 complex-as a target for therapeutic strategies in the treatment of CRC. Breaching the interaction between $\beta$-catenin and Tcf in cancers using small organic molecules will be a hard nut to crack. Yet, some promising results have recently been reported by Shivdasani and colleagues (Lepourcelet et al. 2004). The challenge in the long term will be to translate our increasing knowledge of the biochemical and functional features of the Wnt pathway into effective therapeutic strategies to combat cancer. 


\section{Acknowledgments}

We thank members of the lab for helpful discussions. Part of the work described here was supported by the Center for Biomedical Genetics, Cancer Genomics Consortium, SPINOZA, Louis Jeantet-Foundation, and the Dutch Cancer Foundation KWF.

\section{References}

Alexander, J. and Stainier, D.Y. 1999. A molecular pathway leading to endoderm formation in zebrafish. Curr. Biol. 9: 1147-1157.

Amit, S., Hatzubai, A., Birman, Y., Andersen, J.S., Ben Shushan, E., Mann, M., Ben Neriah, Y., and Alkalay, I. 2002. Axin-mediated CKI phosphorylation of $\beta$-catenin at Ser 45: A molecular switch for the Wnt pathway. Genes \& Dev. 16: 1066-1076.

Andreu, P., Colnot, S., Godard, C., Gad, S., Chafey, P., NiwaKawakita, M., Laurent-Puig, P., Kahn, A., Robine, S., Perret, C., et al. 2005. Crypt-restricted proliferation and commitment to the Paneth cell lineage following Apc loss in the mouse intestine. Development [Epub ahead of print; doi: 10.1242/dev.01700].

Apelqvist, A., Ahlgren, U., and Edlund, H. 1997. Sonic hedgehog directs specialised mesoderm differentiation in the intestine and pancreas. Curr. Biol. 7: 801-804.

Araki, Y., Okamura, S., Hussain, S.P., Nagashima, M., He, P., Shiseki, M., Miura, K., and Harris, C.C. 2003. Regulation of cyclooxygenase- 2 expression by the Wnt and ras pathways. Cancer Res. 63: 728-734.

Arber, N., Doki, Y., Han, E.K., Sgambato, A., Zhou, P., Kim, N.H., Delohery, T., Klein, M.G., Holt, P.R., and Weinstein, I.B. 1997. Antisense to cyclin D1 inhibits the growth and tumorigenicity of human colon cancer cells. Cancer Res. 57: 1569-1574.

Bafico, A., Liu, G., Yaniv, A., Gazit, A., and Aaronson, S.A. 2001. Novel mechanism of Wnt signalling inhibition mediated by Dickkopf-1 interaction with LRP6/Arrow. Nat. Cell Biol. 3: 683-686.

Bafico, A., Liu, G., Goldin, L., Harris, V., and Aaronson, S.A. 2004. An autocrine mechanism for constitutive Wnt pathway activation in human cancer cells. Cancer Cell 6: 497-506.

Barker, N., Hurlstone, A., Musisi, H., Miles, A., Bienz, M., and Clevers, H. 2001. The chromatin remodelling factor Brg-1 interacts with $\beta$-catenin to promote target gene activation. EMBO T. 20: 4935-4943.

Batlle, E., Henderson, J.T., Beghtel, H., van den Born, M.M., Sancho, E., Huls, G., Meeldijk, J., Robertson, J., van de Wetering M., Pawson, T., et al. 2002. $\beta$-Catenin and TCF mediate cell positioning in the intestinal epithelium by controlling the expression of EphB/ephrinB. Cell 111: 251-263.

Behrens, J., von Kries, J.P., Kuhl, M., Bruhn, L., Wedlich, D., Grosschedl, R., and Birchmeier, W. 1996. Functional interaction of $\beta$-catenin with the transcription factor LEF-1. $\mathrm{Na}$ ture 382: 638-642.

Berman, D.M., Karhadkar, S.S., Maitra, A., Montes, D.O., Gerstenblith, M.R., Briggs, K., Parker, A.R., Shimada, Y., Eshleman, J.R., Watkins, D.N., et al. 2003. Widespread requirement for Hedgehog ligand stimulation in growth of digestive tract tumours. Nature 425: 846-851.

Bhanot, P., Brink, M., Samos, C.H., Hsieh, J.C., Wang, Y., Macke, J.P., Andrew, D., Nathans, J., and Nusse, R. 1996. A new member of the frizzled family from Drosophila functions as a Wingless receptor. Nature 382: 225-230.

Bienz, M. and Clevers, H. 2000. Linking colorectal cancer to Wnt signaling. Cell 103: 311-320.

Bijlsma, M.F., Spek, C.A., and Peppelenbosch, M.P. 2004. Hedgehog: An unusual signal transducer. Bioessays 26: 387-394.
Braun, K.M., Niemann, C., Jensen, U.B., Sundberg, J.P., SilvaVargas, V., and Watt, F.M. 2003. Manipulation of stem cell proliferation and lineage commitment: Visualisation of label-retaining cells in wholemounts of mouse epidermis. Development 130: 5241-5255.

Braunstein, E.M., Qiao, X.T., Madison, B., Pinson, K., Dunbar, L., and Gumucio, D.L. 2002. Villin: A marker for development of the epithelial pyloric border. Dev. Dyn. 224: 90-102.

Caldwell, G.M., Jones, C., Gensberg, K., Jan, S., Hardy, R.G., Byrd, P., Chughtai, S., Wallis, Y., Matthews, G.M., and Morton, D.G. 2004. The Wnt antagonist sFRP1 in colorectal tumorigenesis. Cancer Res. 64: 883-888.

Cavallo, R.A., Cox, R.T., Moline, M.M., Roose, J., Polevoy, G.A., Clevers, H., Peifer, M., and Bejsovec, A. 1998. Drosophila Tcf and Groucho interact to repress Wingless signalling activity. Nature 395: 604-608.

Chamorro, M.N., Schwartz, D.R., Vonica, A., Brivanlou, A.H., Cho, K.R., and Varmus, H.E. 2005. FGF-20 and DKK1 are transcriptional targets of $\beta$-catenin and FGF-20 is implicated in cancer and development. EMBO J. 24: 73-84.

Chen, W., ten Berge, D., Brown, J., Ahn, S., Hu, L.A., Miller, W.E., Caron, M.G., Barak, L.S., Nusse, R., and Lefkowitz, R.J. 2003. Dishevelled 2 recruits $\beta$-arrestin 2 to mediate Wnt5A-stimulated endocytosis of Frizzled 4. Science 301: 1391-1394.

Conacci-Sorrell, M.E., Ben Yedidia, T., Shtutman, M., Feinstein, E., Einat, P., and Ben Ze'ev, A. 2002. Nr-CAM is a target gene of the $\beta$-catenin/LEF-1 pathway in melanoma and colon cancer and its expression enhances motility and confers tumorigenesis. Genes \& Dev. 16: 2058-2072.

Easwaran, V., Lee, S.H., Inge, L., Guo, L., Goldbeck, C., Garrett, E., Wiesmann, M., Garcia, P.D., Fuller, J.H., Chan, V., et al. 2003. $\beta$-Catenin regulates vascular endothelial growth factor expression in colon cancer. Cancer Res. 63: 3145-3153.

Eppert, K., Scherer, S.W., Ozcelik, H., Pirone, R., Hoodless, P., Kim, H., Tsui, L.C., Bapat, B., Gallinger, S., Andrulis, I.L., et al. 1996. MADR2 maps to $18 \mathrm{q} 21$ and encodes a TGF $\beta$-regulated MAD-related protein that is functionally mutated in colorectal carcinoma. Cell 86: 543-552.

Fabbro, M. and Henderson, B.R. 2003. Regulation of tumor suppressors by nuclear-cytoplasmic shuttling. Exp. Cell Res. 282: 59-69.

Fearon, E.R. and Vogelstein, B. 1990. A genetic model for colorectal tumorigenesis. Cell 61: 759-767.

Fritsch, C., Swietlicki, E.A., Lefebvre, O., Kedinger, M., Iordanov, H., Levin, M.S., and Rubin, D.C. 2002. Epimorphin expression in intestinal myofibroblasts induces epithelial morphogenesis. J. Clin. Invest 110: 1629-1641.

Fujita, M., Furukawa, Y., Tsunoda, T., Tanaka, T., Ogawa, M., and Nakamura, Y. 2001. Up-regulation of the ectodermalneural cortex 1 (ENC1) gene, a downstream target of the $\beta$-catenin/T-cell factor complex, in colorectal carcinomas. Cancer Res. 61: 7722-7726.

Fukuda, K., Kameda, T., Saitoh, K., Iba, H., and Yasugi, S. 2003. Down-regulation of endodermal $\mathrm{Shh}$ is required for gland formation in chicken stomach. Mech. Dev. 120: 801-809.

Galceran, J., Farinas, I., Depew, M.J., Clevers, H., and Grosschedl, R. 1999. Wnt3 $\mathrm{a}^{-/-}$-like phenotype and limb deficiency in Lef1 ${ }^{-/-}$Tcf1 $^{-/-}$mice. Genes \& Dev. 13: 709-717.

Gregorieff, A., Grosschedl, R., and Clevers, H. 2004. Hindgut defects and transformation of the gastro-intestinal tract in Tcf4-/- Tcf1 $^{-/-}$embryos. EMBO I. 23: 1825-1833.

Groden, J., Thliveris, A., Samowitz, W., Carlson, M., Gelbert, L., Albertsen, H., Joslyn, G., Stevens, J., Spirio, L., Robertson, M., et al. 1991. Identification and characterization of the familial adenomatous polyposis coli gene. Cell 66: 589-600. 
Gupta, R.A., Wang, D., Katkuri, S., Wang, H., Dey, S.K., and Dubois, R.N. 2004. Activation of nuclear hormone receptor peroxisome proliferator-activated receptor- $\delta$ accelerates intestinal adenoma growth. Nat. Med. 10: 245-247.

Hamada, F. and Bienz, M. 2004. The APC tumor suppressor binds to $\mathrm{C}$-terminal binding protein to divert nuclear $\beta$-catenin from TCF. Dev. Cell 7: 677-685.

Haramis, A.P., Begthel, H., van den Born, M., van Es, J., Jonkheer, S., Offerhaus, G.J., and Clevers, H. 2004. De novo crypt formation and juvenile polyposis on BMP inhibition in mouse intestine. Science 303: 1684-1686.

Hardwick, J.C., van den Brink, G.R., Bleuming, S.A., Ballester, I., Van Den Brande, J.M., Keller, J.J., Offerhaus, G.J., Van Deventer, S.J., and Peppelenbosch, M.P. 2004. Bone morphogenetic protein 2 is expressed by, and acts upon, mature epithelial cells in the colon. Gastroenterology 126: 111-121.

Harman, F.S., Nicol, C.J., Marin, H.E., Ward, J.M., Gonzalez, F.J., and Peters, J.M. 2004. Peroxisome proliferator-activated receptor- $\delta$ attenuates colon carcinogenesis. Nat. Med. 10: 481-483.

Hart, M.J., de los Santos, R., Albert, I.N., Rubinfeld, B., and Polakis, P. 1998. Downregulation of $\beta$-catenin by human Axin and its association with the APC tumor suppressor, $\beta$-catenin and GSK3 $\beta$. Curr. Biol. 8: 573-581.

Hart, M., Concordet, J.P., Lassot, I., Albert, I., del los Santos, R., Durand, H., Perret, C., Rubinfeld, B., Margottin, F., Benarous, R., et al. 1999. The F-box protein $\beta$-TrCP associates with phosphorylated $\beta$-catenin and regulates its activity in the cell. Curr. Biol. 9: 207-210.

He, T.C., Sparks, A.B., Rago, C., Hermeking, H., Zawel, L., da Costa, L.T., Morin, P.J., Vogelstein, B., and Kinzler, K.W. 1998. Identification of c-MYC as a target of the APC pathway. Science 281: 1509-1512.

He, T.C., Chan, T.A., Vogelstein, B., and Kinzler, K.W. 1999. PPAR $\delta$ is an APC-regulated target of nonsteroidal anti-inflammatory drugs. Cell 99: 335-345.

He, X.C., Zhang, J., Tong, W.G., Tawfik, O., Ross, J., Scoville, D.H., Tian, Q., Zeng, X., He, X., Wiedemann, L.M., et al. 2004. BMP signaling inhibits intestinal stem cell self-renewal through suppression of Wnt- $\beta$-catenin signaling. Nat. Genet. 36: 1117-1121.

Hecht, A., Vleminckx, K., Stemmler, M.P., van Roy, F., and Kemler, R. 2000. The p300/CBP acetyltransferases function as transcriptional coactivators of $\beta$-catenin in vertebrates. EMBO J. 19: 1839-1850.

Henderson, B.R. 2000. Nuclear-cytoplasmic shuttling of APC regulates $\beta$-catenin subcellular localization and turnover. Nat. Cell Biol. 2: 653-660.

Hovanes, K., Li, T.W., Munguia, J.E., Truong, T., Milovanovic, T., Lawrence, M.J., Holcombe, R.F., and Waterman, M.L. 2001. $\beta$-Catenin-sensitive isoforms of lymphoid enhancer factor-1 are selectively expressed in colon cancer. Nat. Genet. 28: 53-57.

Howe, J.R., Bair, J.L., Sayed, M.G., Anderson, M.E., Mitros, F.A., Petersen, G.M., Velculescu, V.E., Traverso, G., and Vogelstein, B. 2001. Germline mutations of the gene encoding bone morphogenetic protein receptor 1A in juvenile polyposis. Nat. Genet. 28: 184-187.

Howe, J.R., Sayed, M.G., Ahmed, A.F., Ringold, J., LarsenHaidle, J., Merg, A., Mitros, F.A., Vaccaro, C.A., Petersen, G.M., Giardiello, F.M., et al. 2004. The prevalence of MADH4 and BMPR1A mutations in juvenile polyposis and absence of BMPR2, BMPR1B, and ACVR1 mutations. J. Med. Genet. 41: 484-491.

Hsi, L.C., Angerman-Stewart, J., and Eling, T.E. 1999. Introduction of full-length APC modulates cyclooxygenase-2 expres- sion in HT-29 human colorectal carcinoma cells at the translational level. Carcinogenesis 20: 2045-2049.

Hulit, J., Wang, C., Li, Z., Albanese, C., Rao, M., Di Vizio, D., Shah, S., Byers, S.W., Mahmood, R., Augenlicht, L.H., et al. 2004. Cyclin D1 genetic heterozygosity regulates colonic epithelial cell differentiation and tumor number in ApcMin mice. Mol. Cell Biol. 24: 7598-7611.

Ilyas, M., Tomlinson, I.P., Rowan, A., Pignatelli, M., and Bodmer, W.F. 1997. $\beta$-Catenin mutations in cell lines established from human colorectal cancers. Proc. Natl. Acad. Sci. 94: 10330-10334.

Imai, K., Takada, N., Satoh, N., and Satou, Y. 2000. $\beta$-Catenin mediates the specification of endoderm cells in ascidian embryos. Development 127: 3009-3020.

Ireland, H., Kemp, R., Houghton, C., Howard, L., Clarke, A.R. Sansom, O.J., and Winton, D.J. 2004. Inducible Cre-mediated control of gene expression in the murine gastrointestinal tract: Effect of loss of $\beta$-catenin. Gastroenterology 126: $1236-1246$.

Ishikawa, T.O., Tamai, Y., Li, Q., Oshima, M., and Taketo, M.M. 2003. Requirement for tumor suppressor Apc in the morphogenesis of anterior and ventral mouse embryo. Dev. Biol. 253: 230-246.

Ishitani, T., Ninomiya-Tsuji, J., Nagai, S., Nishita, M., Meneghini, M., Barker, N., Waterman, M., Bowerman, B., Clevers, H., Shibuya, H., et al. 1999. The TAK1-NLK-MAPK-related pathway antagonizes signalling between $\beta$-catenin and transcription factor TCF. Nature 399: 798-802.

Jensen, J., Pedersen, E.E., Galante, P., Hald, J., Heller, R.S., Ishibashi, M., Kageyama, R., Guillemot, F., Serup, P., and Madsen, O.D. 2000. Control of endodermal endocrine development by Hes-1. Nat. Genet. 24: 36-44.

Jho, E.H., Zhang, T., Domon, C., Joo, C.K., Freund, J.N., and Costantini, F. 2002. Wnt $/ \beta$-catenin/Tcf signaling induces the transcription of Axin2, a negative regulator of the signaling pathway. Mol. Cell Biol. 22: 1172-1183.

Kadowaki, T., Wilder, E., Klingensmith, J., Zachary, K., and Perrimon, N. 1996. The segment polarity gene porcupine encodes a putative multitransmembrane protein involved in Wingless processing. Genes \& Dev. 10: 3116-3128.

Kaestner, K.H., Silberg, D.G., Traber, P.G., and Schutz, G. 1997. The mesenchymal winged helix transcription factor Fkh6 is required for the control of gastrointestinal proliferation and differentiation. Genes \& Dev. 11: 1583-1595.

Kanai-Azuma, M., Kanai, Y., Gad, J.M., Tajima, Y., Taya, C., Kurohmaru, M., Sanai, Y., Yonekawa, H., Yazaki, K., Tam, P.P., et al. 2002. Depletion of definitive gut endoderm in Sox17-null mutant mice. Development 129: 2367-2379.

Katz, J.P., Perreault, N., Goldstein, B.G., Lee, C.S., Labosky, P.A., Yang, V.W., and Kaestner, K.H. 2002. The zinc-finger transcription factor Klf4 is required for terminal differentiation of goblet cells in the colon. Development 129: 2619-2628.

Kawano, Y. and Kypta, R. 2003. Secreted antagonists of the Wnt signalling pathway. J. Cell Sci. 116: 2627-2634.

Kim, T.H., Xiong, H., Zhang, Z., and Ren, B. 2005. $\beta$-Catenin activates the growth factor endothelin-1 in colon cancer cells. Oncogene 24: 597-604.

Kinzler, K.W. and Vogelstein, B. 1996. Lessons from hereditary colorectal cancer. Cell 87: 159-170.

Kinzler, K.W., Nilbert, M.C., Su, L.K., Vogelstein, B., Bryan, T.M., Levy, D.B., Smith, K.J., Preisinger, A.C., Hedge, P., McKechnie, D., et al. 1991. Identification of FAP locus genes from chromosome 5q21. Science 253: 661-665.

Kitagawa, M., Hatakeyama, S., Shirane, M., Matsumoto, M., Ishida, N., Hattori, K., Nakamichi, I., Kikuchi, A., Nakayama, K., and Nakayama, K. 1999. An F-box protein, FWD1, 
mediates ubiquitin-dependent proteolysis of $\beta$-catenin. EMBO J. 18: 2401-2410.

Koh, T.J., Bulitta, C.J., Fleming, J.V., Dockray, G.J., Varro, A., and Wang, T.C. 2000. Gastrin is a target of the $\beta$-catenin/ TCF-4 growth-signaling pathway in a model of intestinal polyposis. J. Clin. Invest 106: 533-539.

Kolligs, F.T., Nieman, M.T., Winer, I., Hu, G., Van Mater, D., Feng, Y., Smith, I.M., Wu, R., Zhai, Y., Cho, K.R., et al. 2002. ITF-2, a downstream target of the Wnt/TCF pathway, is activated in human cancers with $\beta$-catenin defects and promotes neoplastic transformation. Cancer Cell 1: 145-155.

Korinek, V., Barker, N., Morin, P.J., van Wichen, D., de Weger, R., Kinzler, K.W., Vogelstein, B., and Clevers, H. 1997. Constitutive transcriptional activation by a $\beta$-catenin-Tcf complex in $\mathrm{APC}^{-/-}$colon carcinoma. Science 275: 1784-1787.

Korinek, V., Barker, N., Moerer, P., van Donselaar, E., Huls, G., Peters, P.J., and Clevers, H. 1998. Depletion of epithelial stem-cell compartments in the small intestine of mice lacking Tcf-4. Nat. Genet. 19: 379-383.

Kramps, T., Peter, O., Brunner, E., Nellen, D., Froesch, B., Chatterjee, S., Murone, M., Zullig, S., and Basler, K. 2002. Wnt/ wingless signaling requires BCL9/legless-mediated recruitment of pygopus to the nuclear $\beta$-catenin-TCF complex. Cell 109: 47-60.

Kuhnert, F., Davis, C.R., Wang, H.T., Chu, P., Lee, M., Yuan, J., Nusse, R., and Kuo, C.J. 2004. Essential requirement for Wnt signaling in proliferation of adult small intestine and colon revealed by adenoviral expression of Dickkopf-1. Proc. Natl. Acad. Sci. 101: 266-271.

Lefort, K. and Dotto, G.P. 2004. Notch signaling in the integrated control of keratinocyte growth/differentiation and tumor suppression. Semin. Cancer Biol. 14: 374-386.

Lepourcelet, M., Chen, Y.N., France, D.S., Wang, H., Crews, P., Petersen, F., Bruseo, C., Wood, A.W., and Shivdasani, R.A. 2004. Small-molecule antagonists of the oncogenic Tcf $/ \beta$ catenin protein complex. Cancer Cell 5: 91-102.

Leung, J.Y., Kolligs, F.T., Wu, R., Zhai, Y., Kuick, R., Hanash, S., Cho, K.R., and Fearon, E.R. 2002. Activation of AXIN2 expression by $\beta$-catenin- $\mathrm{T}$ cell factor: A feedback repressor pathway regulating Wnt signaling. J. Biol. Chem. 277: 21657-21665.

Lickert, H., Kutsch, S., Kanzler, B., Tamai, Y., Taketo, M.M., and Kemler, R. 2002. Formation of multiple hearts in mice following deletion of $\beta$-catenin in the embryonic endoderm. Dev. Cell 3: 171-181.

Litingtung, Y., Lei, L., Westphal, H., and Chiang, C. 1998. Sonic hedgehog is essential to foregut development. Nat. Genet. 20: $58-61$.

Liu, P., Wakamiya, M., Shea, M.J., Albrecht, U., Behringer, R.R., and Bradley, A. 1999. Requirement for Wnt3 in vertebrate axis formation. Nat. Genet. 22: 361-365.

Liu, W., Dong, X., Mai, M., Seelan, R.S., Taniguchi, K., Krishnadath, K.K., Halling, K.C., Cunningham, J.M., Boardman, L.A., Qian, C., et al. 2000. Mutations in AXIN2 cause colorectal cancer with defective mismatch repair by activating $\beta$-catenin/TCF signalling. Nat. Genet. 26: 146-147.

Liu, C., Li, Y., Semenov, M., Han, C., Baeg, G.H., Tan, Y., Zhang, Z., Lin, X., and He, X. 2002. Control of $\beta$-catenin phosphorylation/degradation by a dual-kinase mechanism. Cell 108: 837-847.

Lustig, B., Jerchow, B., Sachs, M., Weiler, S., Pietsch, T., Karsten, U., van de Wetering, M., Clevers, H., Schlag, P.M., Birchmeier, W., et al. 2002. Negative feedback loop of Wnt signaling through upregulation of conductin/axin2 in colorectal and liver tumors. Mol. Cell Biol. 22: 1184-1193.

Madison, B.B., Braunstein, K., Kuizon, E., Portman, K., Qiao,
X.T., and Gumucio, D.L. 2005. Epithelial hedgehog signals pattern the intestinal crypt-villus axis. Development 132: 279-289.

Markowitz, S., Wang, J., Myeroff, L., Parsons, R., Sun, L., Lutterbaugh, J., Fan, R.S., Zborowska, E., Kinzler, K.W., Vogelstein, B., et al. 1995. Inactivation of the type II TGF- $\beta$ receptor in colon cancer cells with microsatellite instability. Science 268: 1336-1338.

Marshman, E., Booth, C., and Potten, C.S. 2002. The intestinal epithelial stem cell. Bioessays 24: 91-98.

Massague, J., Blain, S.W., and Lo, R.S. 2000. TGF $\beta$ signaling in growth control, cancer, and heritable disorders. Cell 103: 295-309.

Maunoury, R., Robine, S., Pringault, E., Leonard, N., Gaillard, J.A., and Louvard, D. 1992. Developmental regulation of villin gene expression in the epithelial cell lineages of mouse digestive and urogenital tracts. Development 115: 717-728.

Meneghini, M.D., Ishitani, T., Carter, J.C., Hisamoto, N., Ninomiya-Tsuji, J., Thorpe, C.J., Hamill, D.R., Matsumoto, K., and Bowerman, B. 1999. MAP kinase and Wnt pathways converge to downregulate an HMG-domain repressor in Caenorhabditis elegans. Nature 399: 793-797.

Molenaar, M., van de Wetering M., Oosterwegel, M., PetersonMaduro, J., Godsave, S., Korinek, V., Roose, J., Destree, O., and Clevers, H. 1996. XTcf-3 transcription factor mediates $\beta$-catenin-induced axis formation in Xenopus embryos. Cell 86: 391-399.

Moon, R.T., Kohn, A.D., De Ferrari, G.V., and Kaykas, A. 2004. WNT and $\beta$-catenin signalling: Diseases and therapies. Nat. Rev. Genet. 5: 691-701.

Morin, P.J., Sparks, A.B., Korinek, V., Barker, N., Clevers, H., Vogelstein, B., and Kinzler, K.W. 1997. Activation of $\beta$-catenin-Tcf signaling in colon cancer by mutations in $\beta$-catenin or APC. Science 275: 1787-1790.

Nagase, H. and Nakamura, Y. 1993. Mutations of the APC (adenomatous polyposis coli) gene. Hum. Mutat. 2: 425-434.

Nathke, I.S. 2004. The adenomatous polyposis coli protein: The Achilles heel of the gut epithelium. Annu. Rev. Cell Dev. Biol. 20: 337-366.

Ng, A.Y., Waring, P., Ristevski, S., Wang, C., Wilson, T., Pritchard, M., Hertzog, P., and Kola, I. 2002. Inactivation of the transcription factor Elf3 in mice results in dysmorphogenesis and altered differentiation of intestinal epithelium. Gastroenterology 122: 1455-1466.

Ohtsuka, T., Ishibashi, M., Gradwohl, G., Nakanishi, S., Guillemot, F., and Kageyama, R. 1999. Hes1 and Hes5 as notch effectors in mammalian neuronal differentiation. EMBO $T$. 18: 2196-2207.

Okubo, T. and Hogan, B.L. 2004. Hyperactive Wnt signaling changes the developmental potential of embryonic lung endoderm. J. Biol. 3: 11.

Oshima, M., Oshima, H., Kitagawa, K., Kobayashi, M., Itakura, C., and Taketo, M. 1995. Loss of Apc heterozygosity and abnormal tissue building in nascent intestinal polyps in mice carrying a truncated Apc gene. Proc. Natl. Acad. Sci. 92: 4482-4486.

Oshima, M., Dinchuk, J.E., Kargman, S.L., Oshima, H., Hancock, B., Kwong, E., Trzaskos, J.M., Evans, J.F., and Taketo, M.M. 1996. Suppression of intestinal polyposis in Apc $\delta 716$ knockout mice by inhibition of cyclooxygenase 2 (COX-2). Cell 87: 803-809.

Pabst, O., Zweigerdt, R., and Arnold, H.H. 1999. Targeted disruption of the homeobox transcription factor $\mathrm{Nkx} 2-3$ in mice results in postnatal lethality and abnormal development of small intestine and spleen. Development 126: 22152225 . 
Parker, D.S., Jemison, J., and Cadigan, K.M. 2002. Pygopus, a nuclear PHD-finger protein required for Wingless signaling in Drosophila. Development 129: 2565-2576.

Perreault, N., Katz, J.P., Sackett, S.D., and Kaestner, K.H. 2001. Foxll controls the Wnt $/ \beta$-catenin pathway by modulating the expression of proteoglycans in the gut. J. Biol. Chem. 276: 43328-43333.

Perreault, N., Sackett, S.D., Katz, J.P., Furth, E.E., and Kaestner, K.H. 2005. Foxl1 is a mesenchymal Modifier of Min in carcinogenesis of stomach and colon. Genes \& Dev. 19:311315.

Pinson, K.I., Brennan, J., Monkley, S., Avery, B.J., and Skarnes, W.C. 2000. An LDL-receptor-related protein mediates Wnt signalling in mice. Nature 407: 535-538.

Pinto, D., and Clevers, H. 2005. Wnt, stem cells in the intestine. Biol. Cell 17: 1-12.

Pinto, D., Gregorieff, A., Begthel, H., and Clevers, H. 2003. Canonical Wnt signals are essential for homeostasis of the intestinal epithelium. Genes \& Dev. 17: 1709-1713.

Polakis, P. 2000. Wnt signaling and cancer. Genes \& Dev. 14: $1837-1851$.

Powell, D.W., Mifflin, R.C., Valentich, J.D., Crowe, S.E., Saada, J.I., and West, A.B. 1999. Myofibroblasts, II: Intestinal subepithelial myofibroblasts. Am. J. Physiol 277: C183-C201.

Ramalho-Santos, M., Melton, D.A., and McMahon, A.P. 2000. Hedgehog signals regulate multiple aspects of gastrointestinal development. Development 127: 2763-2772.

Reed, K.R., Sansom, O.J., Hayes, A.J., Gescher, A.J., Winton, D.J., Peters, J.M., and Clarke, A.R. 2004. PPARס status and Apc-mediated tumourigenesis in the mouse intestine. Oncogene 23: 8992-8996.

Roberts, D.J. 2000. Molecular mechanisms of development of the gastrointestinal tract. Dev. Dyn. 219: 109-120.

Rocheleau, C.E., Downs, W.D., Lin, R., Wittmann, C., Bei, Y., Cha, Y.H., Ali, M., Priess, J.R., and Mello, C.C. 1997. Wnt signaling and an APC-related gene specify endoderm in early C. elegans embryos. Cell 90: 707-716.

Rockman, S.P., Currie, S.A., Ciavarella, M., Vincan, E., Dow, C., Thomas, R.J., and Phillips, W.A. 2001. Id2 is a target of the $\beta$-catenin/T cell factor pathway in colon carcinoma. J. Biol. Chem. 276: 45113-45119.

Roose, J., Molenaar, M., Peterson, J., Hurenkamp, J., Brantjes, H., Moerer, P., van de Wetering M., Destree, O., and Clevers, H. 1998. The Xenopus Wnt effector XTcf-3 interacts with Groucho-related transcriptional repressors. Nature 395: 608-612.

Roose, J., Huls, G., van Beest, M., Moerer, P., van der Horn, K., Goldschmeding, R., Logtenberg, T., and Clevers, H. 1999. Synergy between tumor suppressor APC and the $\beta$-cateninTcf4 target Tcf1. Science 285: 1923-1926.

Rosin-Arbesfeld, R., Cliffe, A., Brabletz, T., and Bienz, M. 2003. Nuclear export of the APC tumour suppressor controls $\beta$-catenin function in transcription. EMBO J. 22: 1101-1113.

Rubinfeld, B., Souza, B., Albert, I., Muller, O., Chamberlain, S.H., Masiarz, F.R., Munemitsu, S., and Polakis, P. 1993. Association of the APC gene product with $\beta$-catenin. Science 262: 1731-1734.

Rubinfeld, B., Albert, I., Porfiri, E., Fiol, C., Munemitsu, S., and Polakis, P. 1996. Binding of GSK3 $\beta$ to the APC- $\beta$-catenin complex and regulation of complex assembly. Science 272: 1023-1026.

Russell, R.G., Lasorella, A., Dettin, L.E., and Iavarone, A. 2004. Id 2 drives differentiation and suppresses tumor formation in the intestinal epithelium. Cancer Res. 64: 7220-7225.

Ruzinova, M.B. and Benezra, R. 2003. Id proteins in development, cell cycle and cancer. Trends Cell Biol. 13: 410-418.
Sancho, E., Batlle, E., and Clevers, H. 2004. Signaling pathways in intestinal development and cancer. Annu. Rev. Cell Dev. Biol. 20: 695-723.

Sansom, O.J., Reed, K.R., Hayes, A.J., Ireland, H., Brinkmann, H., Newton, I.P., Batlle, E., Simon-Assmann, P., Clevers, H., Nathke, I.S., et al. 2004. Loss of Apc in vivo immediately perturbs Wnt signaling, differentiation, and migration. Genes \& Dev. 18: 1385-1390.

Sasaki, T., Suzuki, H., Yagi, K., Furuhashi, M., Yao, R., Susa, S., Noda, T., Arai, Y., Miyazono, K., and Kato, M. 2003. Lymphoid enhancer factor 1 makes cells resistant to transforming growth factor $\beta$-induced repression of c-myc. Cancer Res. 63: $801-806$.

Schonhoff, S.E., Giel-Moloney, M., and Leiter, A.B. 2004. Minireview: Development and differentiation of gut endocrine cells. Endocrinology 145: 2639-2644.

Sekiya, T., Adachi, S., Kohu, K., Yamada, T., Higuchi, O., Furukawa, Y., Nakamura, Y., Nakamura, T., Tashiro, K., Kuhara, S., et al. 2004. Identification of BMP and activin membrane-bound inhibitor (BAMBI), an inhibitor of transforming growth factor- $\beta$ signaling, as a target of the $\beta$-catenin pathway in colorectal tumor cells. J. Biol. Chem. 279: 6840-6846.

Shimokawa, T., Furukawa, Y., Sakai, M., Li, M., Miwa, N., Lin, Y.M., and Nakamura, Y. 2003. Involvement of the FGF18 gene in colorectal carcinogenesis, as a novel downstream target of the $\beta$-catenin/T-cell factor complex. Cancer Res. 63: 6116-6120.

Shtutman, M., Zhurinsky, J., Simcha, I., Albanese, C., D'Amico, M., Pestell, R., and Ben Ze'ev, A. 1999. The cyclin D1 gene is a target of the $\beta$-catenin/LEF-1 pathway. Proc. Natl. Acad. Sci. 96: 5522-5527.

Sinner, D., Rankin, S., Lee, M., and Zorn, A.M. 2004. Sox17 and $\beta$-catenin cooperate to regulate the transcription of endodermal genes. Development 131: 3069-3080.

Sterner-Kock, A., Thorey, I.S., Koli, K., Wempe, F., Otte, J., Bangsow, T., Kuhlmeier, K., Kirchner, T., Jin, S., Keski-Oja, J., et al. 2002. Disruption of the gene encoding the latent transforming growth factor- $\beta$ binding protein 4 (LTBP-4) causes abnormal lung development, cardiomyopathy, and colorectal cancer. Genes \& Dev. 16: 2264-2273.

Sukegawa, A., Narita, T., Kameda, T., Saitoh, K., Nohno, T., Iba, H., Yasugi, S., and Fukuda, K. 2000. The concentric structure of the developing gut is regulated by Sonic hedgehog derived from endodermal epithelium. Development 127: 1971-1980.

Suzuki, H., Watkins, D.N., Jair, K.W., Schuebel, K.E., Markowitz, S.D., Dong, C.W., Pretlow, T.P., Yang, B., Akiyama, Y., Van Engeland, M., et al. 2004. Epigenetic inactivation of SFRP genes allows constitutive WNT signaling in colorectal cancer. Nat. Genet. 36: 417-422.

Tago, K., Nakamura, T., Nishita, M., Hyodo, J., Nagai, S., Murata, Y., Adachi, S., Ohwada, S., Morishita, Y., Shibuya, H., et al. 2000. Inhibition of Wnt signaling by ICAT, a novel $\beta$-catenin-interacting protein. Genes \& Dev. 14: 1741-1749.

Takagi, Y., Kohmura, H., Futamura, M., Kida, H., Tanemura, H., Shimokawa, K., and Saji, S. 1996. Somatic alterations of the DPC4 gene in human colorectal cancers in vivo. Gastroenterology 111: 1369-1372.

Takahashi, M., Fujita, M., Furukawa, Y., Hamamoto, R., Shimokawa, T., Miwa, N., Ogawa, M., and Nakamura, Y. 2002. Isolation of a novel human gene, APCDD1, as a direct target of the $\beta$-catenin/T-cell factor 4 complex with probable involvement in colorectal carcinogenesis. Cancer Res. 62: 5651-5656.

Takemaru, K.I. and Moon, R.T. 2000. The transcriptional coactivator CBP interacts with $\beta$-catenin to activate gene expression. J. Cell Biol. 149: 249-254. 
Takemaru, K., Yamaguchi, S., Lee, Y.S., Zhang, Y., Carthew, R.W., and Moon, R.T. 2003. Chibby, a nuclear $\beta$-cateninassociated antagonist of the Wnt/Wingless pathway. Nature 422: 905-909.

Tamai, K., Semenov, M., Kato, Y., Spokony, R., Liu, C., Katsuyama, Y., Hess, F., Saint-Jeannet, J.P., and He, X. 2000. LDL-receptor-related proteins in Wnt signal transduction. Nature 407: 530-535.

Tamai, K., Zeng, X., Liu, C., Zhang, X., Harada, Y., Chang, Z., and He, X. 2004. A mechanism for Wnt coreceptor activation. Mol. Cell 13: 149-156.

Tetsu, O. and McCormick, F. 1999. $\beta$-Catenin regulates expression of cyclin D1 in colon carcinoma cells. Nature 398: 422426.

Thayer, S.P., di Magliano, M.P., Heiser, P.W., Nielsen, C.M., Roberts, D.J., Lauwers, G.Y., Qi, Y.P., Gysin, S., Fernandezdel Castillo, C., Yajnik, V., et al. 2003. Hedgehog is an early and late mediator of pancreatic cancer tumorigenesis. $\mathrm{Na}$ ture 425: 851-856.

Thompson, B., Townsley, F., Rosin-Arbesfeld, R., Musisi, H., and Bienz, M. 2002. A new nuclear component of the Wnt signalling pathway. Nat. Cell Biol. 4: 367-373.

Townsley, F.M., Cliffe, A., and Bienz, M. 2004. Pygopus and Legless target Armadillo/ $\beta$-catenin to the nucleus to enable its transcriptional co-activator function. Nat. Cell Biol. 6: 626-633.

Tsuda, M., Kamimura, K., Nakato, H., Archer, M., Staatz, W., Fox, B., Humphrey, M., Olson, S., Futch, T., Kaluza, V., et al. 1999. The cell-surface proteoglycan Dally regulates Wingless signalling in Drosophila. Nature 400: 276-280.

van Amerongen, R., Nawijn, M., Franca-Koh, J., Zevenhoven, J., van der Gulden, H., Jonkers, J., and Berns, A. 2005. Frat is dispensable for canonical Wnt signaling in mammals. Genes \& Dev. 19: 425-430.

van de Wetering, M., Sancho, E., Verweij, C., de Lau, W., Oving, I., Hurlstone, A., van der Horn, K., Batlle, E., Coudreuse, D., Haramis, A.P., et al. 2002. The $\beta$-catenin/TCF-4 complex imposes a crypt progenitor phenotype on colorectal cancer cells. Cell 111: 241-250.

van de Wetering, M., Oving, I., Muncan, V., Pon Fong, M.T., Brantjes, H., van Leenen, D., Holstege, F.C., Brummelkamp, T.R., Agami, R., and Clevers, H. 2003. Specific inhibition of gene expression using a stably integrated, inducible smallinterfering-RNA vector. EMBO Rep. 4: 609-615.

van den Brink, G.R., Bleuming, S.A., Hardwick, J.C., Schepman, B.L., Offerhaus, G.J., Keller, J.J., Nielsen, C., Gaffield, W., Van Deventer, S.J., Roberts, D.J., et al. 2004. Indian Hedgehog is an antagonist of Wnt signaling in colonic epithelial cell differentiation. Nat. Genet. 36: 277-282.

van den Heuvel, M., Harryman-Samos, C., Klingensmith, J., Perrimon, N., and Nusse, R. 1993. Mutations in the segment polarity genes wingless and porcupine impair secretion of the wingless protein. EMBO I. 12: 5293-5302.

van Es, J.H., Jay, P., Gregorieff, A., van Gijn, M.E., Jonkheer, S., Hatzis, P., Thiele, A., van den Born, M., Begthel, H., Brabletz, T., et al. 2005. Wnt signaling induces maturation of Paneth cells in intestinal crypts. Nat. Cell Biol. (in press).

Veeman, M.T., Axelrod, J.D., and Moon, R.T. 2003. A second canon: Functions and mechanisms of $\beta$-catenin-independent Wnt signaling. Dev. Cell 5: 367-377.

Waite, K.A. and Eng, C. 2003. From developmental disorder to heritable cancer: It's all in the BMP/TGF- $\beta$ family. Nat. Rev. Genet. 4: 763-773.

Waterman, M.L. 2004. Lymphoid enhancer factor/T cell factor expression in colorectal cancer. Cancer Metastasis Rev. 23: $41-52$.
Wehrli, M., Dougan, S.T., Caldwell, K., O'Keefe, L., Schwartz, S., Vaizel-Ohayon, D., Schejter, E., Tomlinson, A., and DiNardo, S. 2000. arrow encodes an LDL-receptor-related protein essential for Wingless signalling. Nature 407: 527-530.

Wells, J.M. and Melton, D.A. 1999. Vertebrate endoderm development. Annu. Rev. Cell Dev. Biol. 15: 393-410.

Willert, K., Brown, J.D., Danenberg, E., Duncan, A.W., Weissman, I.L., Reya, T., Yates III, J.R., and Nusse, R. 2003. Wnt proteins are lipid-modified and can act as stem cell growth factors. Nature 423: 448-452.

Wilson, C.L., Heppner, K.J., Labosky, P.A., Hogan, B.L., and Matrisian, L.M. 1997. Intestinal tumorigenesis is suppressed in mice lacking the metalloproteinase matrilysin. Proc. Natl. Acad. Sci. 94: 1402-1407.

Winston, J.T., Strack, P., Beer-Romero, P., Chu, C.Y., Elledge, S.J., and Harper, J.W. 1999. The SCF $\beta-T R C P-$ ubiquitin ligase complex associates specifically with phosphorylated destruction motifs in IкB $\alpha$ and $\beta$-catenin and stimulates IкB $\alpha$ ubiquitination in vitro. Genes \& Dev. 13: 270-283.

Wodarz, A. and Nusse, R. 1998. Mechanisms of Wnt signaling in development. Annu. Rev. Cell Dev. Biol. 14: 59-88.

Wong, N.A. and Pignatelli, M. 2002. $\beta$-Catenin: A linchpin in colorectal carcinogenesis? Am. J. Pathol. 160: 389-401.

Wong, H.C., Bourdelas, A., Krauss, A., Lee, H.J., Shao, Y., Wu, D., Mlodzik, M., Shi, D.L., and Zheng, J. 2003. Direct binding of the PDZ domain of Dishevelled to a conserved internal sequence in the C-terminal region of Frizzled. Mol. Cell 12: $1251-1260$.

Yamada, T., Takaoka, A.S., Naishiro, Y., Hayashi, R., Maruyama, K., Maesawa, C., Ochiai, A., and Hirohashi, S. 2000. Transactivation of the multidrug resistance 1 gene by $\mathrm{T}$-cell factor $4 / \beta$-catenin complex in early colorectal carcinogenesis. Cancer Res. 60: 4761-4766.

Yamada, T., Mori, Y., Hayashi, R., Takada, M., Ino, Y., Naishiro, Y., Kondo, T., and Hirohashi, S. 2003. Suppression of intestinal polyposis in Mdr1-deficient $\mathrm{Apc}^{\mathrm{Min} /+}$ mice. Cancer Res. 63: 895-901.

Yang, Q., Bermingham, N.A., Finegold, M.J., and Zoghbi, H.Y. 2001. Requirement of Math1 for secretory cell lineage commitment in the mouse intestine. Science 294: 2155-2158.

Yang, J., Wu, J., Tan, C., and Klein, P.S. 2003. PP2A:B56e is required for Wnt $/ \beta$-catenin signaling during embryonic development. Development 130: 5569-5578.

Yost, C., Farr III, G.H., Pierce, S.B., Ferkey, D.M., Chen, M.M., and Kimelman, D. 1998. GBP, an inhibitor of GSK-3, is implicated in Xenopus development and oncogenesis. Cell 93: 1031-1041.

Zhang, T., Otevrel, T., Gao, Z., Gao, Z., Ehrlich, S.M., Fields, J.Z., and Boman, B.M. 2001. Evidence that APC regulates survivin expression: A possible mechanism contributing to the stem cell origin of colon cancer. Cancer Res. 61: 8664-8667.

Zheng, J.L., Shou, J., Guillemot, F., Kageyama, R., and Gao, W.Q. 2000. Hes1 is a negative regulator of inner ear hair cell differentiation. Development 127: 4551-4560.

Zhou, X.P., Woodford-Richens, K., Lehtonen, R., Kurose, K., Aldred, M., Hampel, H., Launonen, V., Virta, S., Pilarski, R., Salovaara, R., et al. 2001. Germline mutations in BMPR1A/ ALK3 cause a subset of cases of juvenile polyposis syndrome and of Cowden and Bannayan-Riley-Ruvalcaba syndromes. Am. J. Hum. Genet. 69: 704-711.

Zhu, Y., Richardson, J.A., Parada, L.F., and Graff, J.M. 1998. Smad3 mutant mice develop metastatic colorectal cancer. Cell 94: 703-714.

Zhu, P., Martin, E., Mengwasser, J., Schlag, P., Janssen, K.P., and Gottlicher, M. 2004. Induction of HDAC2 expression upon loss of APC in colorectal tumorigenesis. Cancer Cell 5: 455-463. 


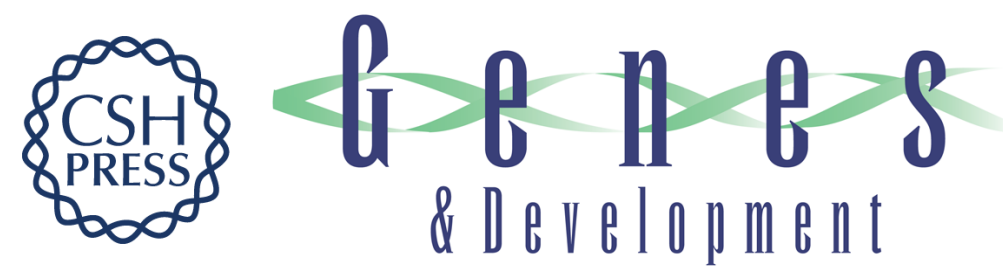

\section{Wnt signaling in the intestinal epithelium: from endoderm to cancer}

Alex Gregorieff and Hans Clevers

Genes Dev. 2005, 19:

Access the most recent version at doi:10.1101/gad.1295405

References This article cites 164 articles, 72 of which can be accessed free at: http://genesdev.cshlp.org/content/19/8/877.full.html\#ref-list-1

License

Email Alerting Receive free email alerts when new articles cite this article - sign up in the box at the top Service right corner of the article or click here.

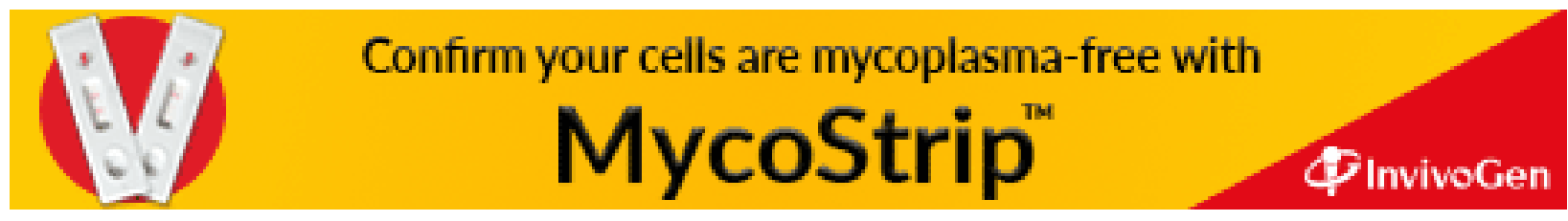

